\title{
Incubation experiment demonstrates effects of carbon and nitrogen on microbial phosphate-solubilizing function
}

\author{
Hongyang Sun, Yanhong $\mathrm{Wu}^{*}$, Jun Zhou \& Haijian Bing \\ Key Laboratory of Mountain Surface Process and Ecological Regulation, Institute of Mountain Hazards and Environment, Chinese Academy \\ of Sciences, Chengdu 610041, China
}

Received August 26, 2016; accepted October 8, 2016; published online November 23, 2016

Citation: Sun, H., Wu, Y., Zhou, J., and Bing, H. (2016). Incubation experiment demonstrates effects of carbon and nitrogen on microbial phosphate-solubilizing function. Sci China Life Sci 60, 436-438. doi: 10.1007/s11427-016-0242-1

Dear Editor,

Phosphorus $(\mathrm{P})$ ultimately comes from rock weathering in natural ecosystems (Porder et al., 2007), and thus solubilization of rock phosphate plays a crucial ecological role in $\mathrm{P}$ supply for the ecosystems. Especially, microbial solubilization of rock phosphate is a vital process for the replenishment of available $\mathrm{P}$ in alpine ecosystems where the weathering degree of soil is low. The phosphate solubilizing microorganisms (PSM), major participants in the process, are directly affected by carbon $(\mathrm{C})$ and nitrogen $(\mathrm{N})$ sources. Given that the $\mathrm{C} / \mathrm{N}$ stoichiometry affects the microbial community structure and biomass (Cleveland and Liptzin, 2007; Waring et al., 2013), we speculated that the levels and ratios of $\mathrm{C}$ and $\mathrm{N}$ regulate the phosphate-solubilizing function of PSM communities in alpine soils. In addition, global changes and anthropogenic activities have led to $\mathrm{N}$ deposition and elevated atmospheric $\mathrm{CO}_{2}$. As a sensitive zone, soil $\mathrm{C}$ and $\mathrm{N}$ of alpine regions is likely to change, and then affect microbial phosphate-solubilizing function. Therefore, it is necessary to clarify the influences of soil $\mathrm{C}$ and $\mathrm{N}$ on the phosphate-solubilizing function of microbial communities in alpine soils to improve understanding of the effect of global changes on alpine P cycle.

A microbial phosphate-solubilizing experiment with different levels and ratios of $\mathrm{C}$ and $\mathrm{N}$ was conducted by using soil

*Corresponding author (email: yanhong_wu@yeah.net) samples that were collected from three alpine zones in 3,000, 3,600 and 4,200 $\mathrm{m}$ above sea level (asl) on Gongga Mountain (Tables S1 and S2 in Supporting Information). The results showed that the responses of different PSM communities to the same treatments were markedly different.

The indicators of phosphate-solubilizing efficiency (PSE, i.e., total amount of dissolved phosphorus (TDP) and $\mathrm{PO}_{4}{ }^{3-}$ concentration) increased with the increasing $\mathrm{C} / \mathrm{N}$ ratios when $\mathrm{N}$ level was set as a constant (Figure 1A and D). In contrast, the responses of PSE were completely different to the $\mathrm{C} / \mathrm{N}$ ratios when $\mathrm{C}$ level was set as a constant (Figure $1 \mathrm{~B}$ and $\mathrm{E}$ ): two patterns were found: (i) the PSE increased with the decreasing $\mathrm{C} / \mathrm{N}$ ratios for the 3,000 and 3,600 m PSM-Communities, which was completely opposite to the above case (i.e., Figure $1 \mathrm{~A}$ and D); (ii) the PSE at $\mathrm{C} / \mathrm{N}=34$ was lower than that at $\mathrm{C} / \mathrm{N}=6.2$ and 137 for the 4,200 m PSM-Community, indicating that $\mathrm{C} / \mathrm{N}=34$ resulted in the lowest $\mathrm{P}$ yields.

When the $\mathrm{C} / \mathrm{N}$ ratio was 34 , the PSE of the 3,000 and 4,200 $\mathrm{m}$ PSM-Communities was higher under high $\mathrm{C}$ and $\mathrm{N}$ levels compared with that under low $\mathrm{C}$ and $\mathrm{N}$ levels (Figure $1 \mathrm{C}$ and $\mathrm{F})$. The same results were observed when $\mathrm{C} / \mathrm{N}$ ratios were 6.2 and 137 (Figures S1 and S2 in Supporting Information). However, the PSE of the 3,600 m PSM-Community under high $\mathrm{C}$ and $\mathrm{N}$ levels was lower than that under low $\mathrm{C}$ and $\mathrm{N}$ levels when the $\mathrm{C} / \mathrm{N}$ ratio was 34 , though the difference was not significant (Figure $1 \mathrm{C}$ and F).

To explore the response mechanism of PSM-Commu- 
nity to $\mathrm{C}$ and $\mathrm{N}$, the $\mathrm{pH}$ and microbial phospholipid fatty acids (PLFAs) were measured. Generally, the secretion of acids, which might change soil $\mathrm{pH}$, is a primary mechanism of phosphate solubilization by PSM (Goldstein, 1995; Kim et al., 1997). Our results showed that the $\mathrm{pH}$ values were lower in all treatments than that in the control check group (i.e. CK treatments) (Figure S3 in Supporting Information). The PLFAs can represent microbial growth as a biomass indicator. The results showed that a higher microbial PLFA concentration did not always lead to a higher PSE. For example, for the 4,200 m PSM-Community, the PSE decreased (Figure 1B and E) while the microbial PLFAs increased (Figure $1 \mathrm{G}$ and $\mathrm{H}$ ) with the decrease of $\mathrm{C} / \mathrm{N}$ from 137 to $34(\mathrm{C}=364 \mathrm{mg})$; in contrast, when the $\mathrm{C} / \mathrm{N}$ continuously decreased from 34 to 6.2 , the PSE increased while the microbial PLFAs decreased. It indicated that the metabolic behaviour of the PSM-Community was redirected between phosphate dissolution and microbial growth under the influence of $\mathrm{C}$ and $\mathrm{N}$. In addition, for the 3,000 m PSM-Community, the significant changes occurred in fungi PLFAs and bacteria
PLFAs with the decrease of $\mathrm{C} / \mathrm{N}$ from 137 to $34(\mathrm{C}=364 \mathrm{mg})$ (Figure $1 \mathrm{G}$ and $\mathrm{H}$ ). Meanwhile, the TDP had also significant changes (Figure 1A) while the $\mathrm{pH}$ values did not have significant changes (Figure 1I) under this treatment. It suggested that the change of community structure was also a response mechanism of PSM-Community to $\mathrm{C}$ and $\mathrm{N}$.

This study experimentally demonstrates that the ratios (or levels) of $\mathrm{C}$ and $\mathrm{N}$, as a single indicator, is likely to be unreliable to assess effects of $\mathrm{C}$ and $\mathrm{N}$ on the microbial function, and thus it is very necessary to use a combination of the ratios and levels of $\mathrm{C}$ and $\mathrm{N}$ for a correct conclusion. In addition, $\mathrm{C}$ and $\mathrm{N}$ affect the phosphate-solubilizing function of microbial communities in alpine soils by their ratio and level. The PSE responses of PSM communities differ between different alpine ecosystems to the same conditions of $\mathrm{C}$ and $\mathrm{N}$. The changes in the $\mathrm{pH}$, microbial community structure and metabolic behaviour contributed to these responses of PSE. These results imply also that global changes are altering the biogeochemical processes of $\mathrm{P}$ in alpine soil ecosystems via
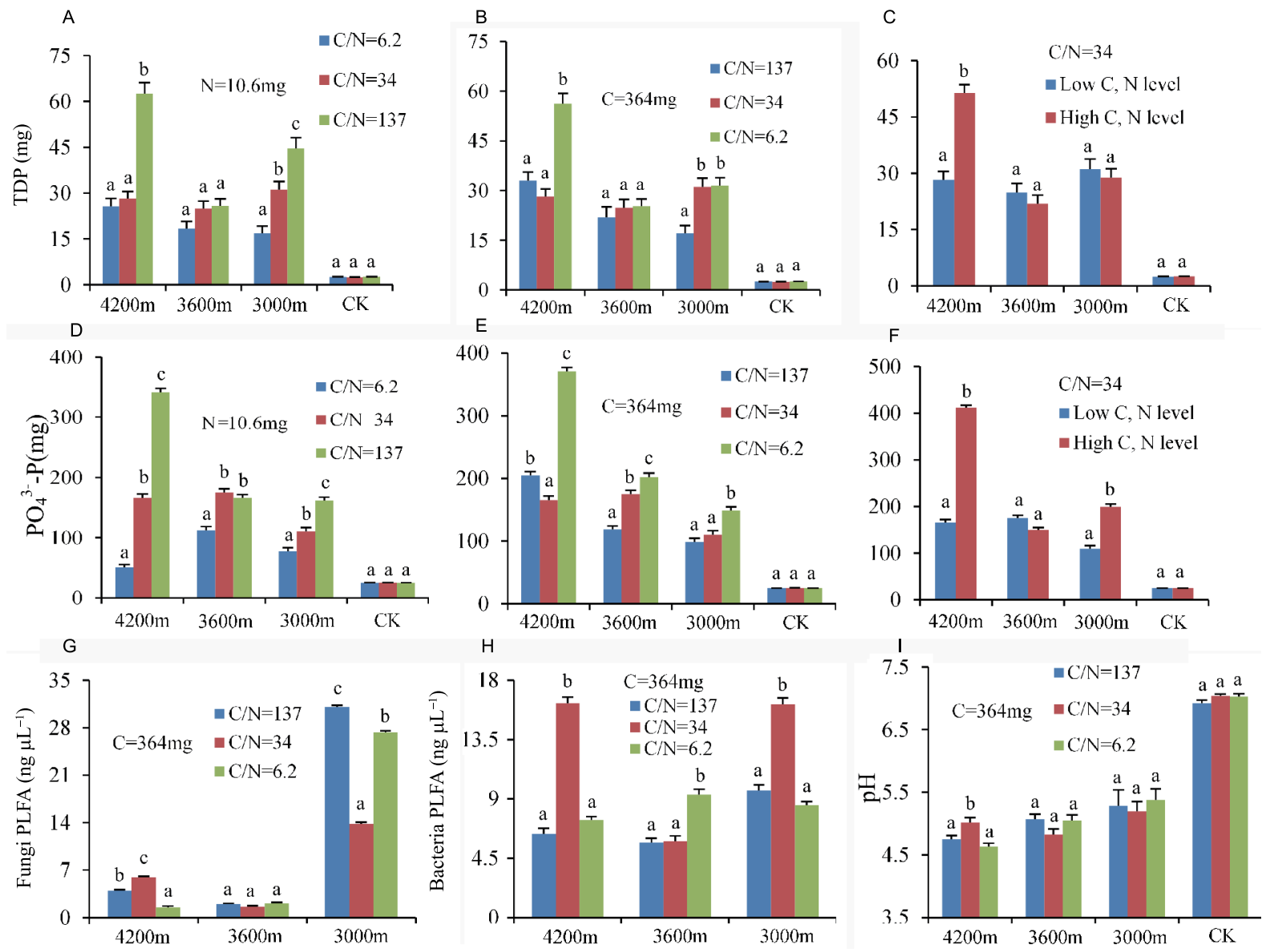

Figure 1 Effects of $\mathrm{C}$ and $\mathrm{N}$ on PSM-Communities from the three alpine zones. 4,200 m, the 4,200 m PSM-Community; 3,600 m, the 3,600 m PSM-Community; 3,000 m, the 3,000 m PSM-Community; CK, a control check group without treatments; TDP, total amount of dissolved phosphorus; PO ${ }_{4}{ }^{3-}$-P, $\mathrm{P}$ in the form of $\mathrm{PO}_{4}{ }^{3-}$. Low $\mathrm{C}, \mathrm{N}$ level, $\mathrm{C}=364 \mathrm{mg}$ and $\mathrm{N}=10.6 \mathrm{mg}$; High $\mathrm{C}, \mathrm{N}$ level, $\mathrm{C}=1,455 \mathrm{mg}$ and $\mathrm{N}=42.5 \mathrm{mg}$. The fatty acids 14:0, 15:0, i14:0, a15:0, i15:0, i16:0,

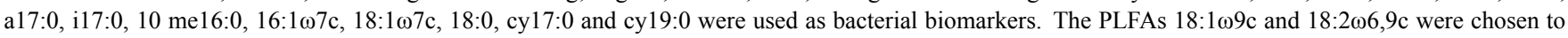
represent fungi. The different letters indicate significant difference (at $P<0.05)$. The error bar represents the standard error $(n=6)$. 
changes in $\mathrm{C}$ and $\mathrm{N}$. This study will improve understanding the response of PSM to the variations of $\mathrm{C}$ and $\mathrm{N}$ in the alpine soils.

Compliance and ethics The author(s) declare that they have no conflict of interest.

Acknowledgements This work was supported by the Chinese Academy of Sciences (CAS "Light of West China” Program), the National Natural Science Foundation of China (281, 41272200), and the open fund of Key Laboratory of Mountain Surface Process and Ecological Regulation, Institute of Mountain Hazards and Environment.
Cleveland, C.C., and Liptzin, D. (2007). C:N:P stoichiometry in soil: is there a "Redfield ratio" for the microbial biomass?. Biogeochemistry $85,235-252$

Goldstein, A.H. (1995). Recent progress in understanding the molecular genetics and biochemistry of calcium phosphate solubilization by gram negative bacteria. Biol Agricul Horticul 12, 185-193.

Kim, K.Y., Jordan, D., and Krishnan, H.B. (1997). Rahnella aquatilis, a bacterium isolated from soybean rhizosphere, can solubilize hydroxyapatite. FEMS Microbiol Lett 153, 273-277.

Porder, S., Vitousek, P.M., Chadwick, O.A., Chamberlain, C.P., and Hilley, G.E. (2007). Uplift, erosion, and phosphorus limitation in terrestrial ecosystems. Ecosystems 10, 159-171.

Waring, B.G., Averill, C., and Hawkes, C.V. (2013). Differences in fungal and bacterial physiology alter soil carbon and nitrogen cycling: insights from meta-analysis and theoretical models. Ecol Lett 16, 887-894.

Open Access This article is distributed under the terms of the Creative Commons Attribution License which permits any use, distribution, and reproduction in any medium, provided the original author(s) and source are credited.

\section{SUPPORTING INFORMATION}

Table S1 Site information and soil properties

Table S2 Phosphate-solubilizing experiments design

Figure S1 Phosphate-solubilizing efficiency under different $\mathrm{C}$ and $\mathrm{N}$ levels when $\mathrm{C} / \mathrm{N}=6.2$. Low $\mathrm{C}, \mathrm{N}$ level: $\mathrm{C}=65.6 \mathrm{mg}$ and $\mathrm{N}=10.6 \mathrm{mg}$; High $\mathrm{C}$, $\mathrm{N}$ level: $\mathrm{C}=364 \mathrm{mg}$ and $\mathrm{N}=58.8 \mathrm{mg}$.

Figure S2 Phosphate-solubilizing efficiency under different $\mathrm{C}$ and $\mathrm{N}$ levels when $\mathrm{C} / \mathrm{N}$ ratio=137. Low $\mathrm{C}, \mathrm{N}$ level: $\mathrm{C}=364 \mathrm{mg}$ and $\mathrm{N}=2.65 \mathrm{mg} ;$ High $\mathrm{C}$, $\mathrm{N}$ level: $\mathrm{C}=1,455 \mathrm{mg}$ and $\mathrm{N}=10.6 \mathrm{mg}$.

Figure S3 The $\mathrm{pH}$ values with the different treatments of $\mathrm{C}$ and $\mathrm{N}$.

The supporting information is available online at life.scichina.com and www.springerlink.com. The supporting materials are published as submitted, without typesetting or editing. The responsibility for scientific accuracy and content remains entirely with the authors. 